\title{
MACROPHYTES BIODIVERSITY OF WAIGAON TUKUM LAKE NEAR BHADRAWATI, DISTRICT CHANDRAPUR (M.S.), INDIA
}

\author{
Harney, N.V. \\ Institution of Higher Learning, Research and Specialized Studies in the Subject \\ Zoology, Dept. of Zoology, Nilkanthrao Shinde Science and Arts College, \\ Bhadrawati, District - Chandrapur(M.S.), India \\ Email Id- narendra_harney2008@rediffmail.com
}

Communicated : 16.12.19 Revision : 04.01.2020

Accepted : 21.01.2020

Published: 30.01 .2020

\begin{abstract}
:
Macrophytes are the conspicuous plants that dominate wetlands, shallow lakes, and streams. Macroscopic flora include the aquatic angiosperms (flowering plants), pteridophytes (ferns), and bryophytes (mosses, hornworts, and liverworts). In lakes macrophytes provide cover for fish and substrate for aquatic invertebrates, produce oxygen, and act as food for some fish and wildlife. Macrophytes is an important factors for helping in maintaining ecological balance. Aquatic macrophytes play a pivotal role in maintaining primary productivity of water ecosystem. Aquatic macrophytes includes a vast majority of aquatic vascular plants. They are found mainly in the shallow regions of ponds, lakes, rivers, swamps and streams etc. They are of considerable ecological and economical importance. The present paper describes the macrophytes biodiversity of Waigaon Tukum lake near Bhadrawati of Chandrapur district of Maharashtra State from January 2015 to December 2017 in which 26 species representing 17 families belonging to 08 groups such as 03 Submerged floating weeds, 03 Rooted floating leaves weeds, 01 Rooted emergent with heterophile weeds, 06 Free floating suspended submerged, 03 Rooted submerged hydrophytes, 07 Emergent weeds, 02 Submerged weeds and 01 Anchored floating weeds.
\end{abstract}

Key words: - Macrophytes, Waigaon Tukum, Biodiversity

\section{INTRODUCTION:}

An aquatic plant can be defined as one that is normally found growing in association with standing water whose level is at or above the surface of the soil. Standing water includes ponds, shallow lakes, marshes, ditches, reservoirs, swamps, bogs, canals, and sewage lagoons. Aquatic plants, though less frequently, also occur in flowing water, in streams, rivers, andsprings.

Aquatic macrophytes play a vital role in healthy ecosystems. They serve as primary producers of oxygen through photosynthesis, provide a substrate for algae and shelter for many invertebrates, aid in nutrient cycling to and from the sediments, and help stabilize river and stream banks.
The Waigaon Tukum lake is principal freshwater body located $35 \mathrm{~km}$ from Bhadrawati, Chandrapur district, Maharashtra State, India. It is situtated at about $715 \mathrm{~m}$ above MSL and at $20^{\circ} 14^{1} 17.6711 \mathrm{~N}$ latitude and $79^{\circ} 15^{110} .13^{11} \mathrm{E}$ longitude and the area of Waigaon Tukum lake is 71.661 acre. Aquatic macrophytes are also respond to the changes in water quality and have been used as indicator of pollution of pollution in several cases (Westtake, 1981 and Best, 1982).

During the last few decades considerable studies on aquatic macrophytes from different freshwater bodies of India and abroad have been carried out by researchers like, Unni, (1971), Crowder et al., (1977), Zutshi et al., (1980), Billore and Vyas (1981), Islam (1990), Kodarkar, (1996), Salaskar, (1998), Dey and Kar (1999), Bhaumiket 
al., (2004), Kumar and Pandit (2005), Ghavzan et al., (2006), Devi and Sharma (2007) and so on.

\section{MATERIAL AND METHODS:-}

The aquatic macrophytes were collected for the period of 2 years i.e. January 2015 to December 2017. Macrophytes in shallow waters were collected directly while those from deeper water with the help of long handled hook. On collection the specimen were thoroughly washed, excess water soaked with filter paper, kept in polythene bags lined with filter paper and brought to the laboratory and preserved in $10 \%$ formalin and observed. The specimens were identified up to species level as per the guidelines of Kodarkar(1994).

\section{RESULTS AND DISCUSSION}

Aquatic macrophytes play a vital role in healthy ecosystems. They serve as primary producers of oxygen through photosynthesis, provide a substrate for algae and shelter for many invertebrates, aid in nutrient cycling to and from the sediments, and help stabilize river and stream banks.

Aquatic macrophytes have served humans well over the centuries, providing food, medicines, and building materials. The ancient Egyptians regularly harvested water lilies (Nymphaea sp.) for human consumption. Aquatic macrophytes have served humans well over the centuries, providing food, medicines, and building materials. The ancient Egyptians regularly harvested water lilies (Nymphaeaspp.) for human consumption. Herodotus, the Greek historian, described the practice in the fifth century BC; lilies were dried and seeds were pounded or ground into flour, which was used to make bread. Other parts were eaten raw. Various Nymphaea sp. are still cultivated in the orient for their fruits, seeds, and rhizomes. In Africa, various tribes dig up the starch-laden rhizomes for food.
Aquatic plants serves as a good source of food to mankind and animals thus forming a palatable food for water birds and a best for aquatic wild life conservation practices (Kiranet al., 2006). Aquatic vesicular plants are important indicator of water pollution (Seddon, 1972 and Shimoda, 1984). Aquatic plants are important as they serve as substratum to different micro and macro fauna (Raut and Pejawar, 2005). Macrophytes provide habitats for fish and smaller animals; they bind sediments, protect banks, absorb nutrients and provide oxygenation. Macrophytes can indicate the impact of increased nutrients in lakes and are also influenced by other pressures such as water level change or acidification.

In the present study altogether 26 species representing 17 families belonging to 8 groups such as 03 Submerged floating weeds, 03 Rooted floating leaves weeds, 01 Rooted emergent with heterophile weeds, 06 Free floating suspended submerged, 03 Rooted submerged hydrophytes, 07 Emergent weeds, 02 Submerged weeds and 01 Anchored floating weeds. The data is tabulated in Table No. 1.

Submerged floating weeds represented by three species such as Vallisneriaamericana, Myriophyllumexalbescensand

Ceratophyllumechinatum. Submerged weeds are weeds that are rooted on the bottom of the pond, Floating weeds are plants that float on the surface of the pond orlake.

Rooted floating leaves weeds represented by three species such as Nymphaea tuberose, Nelumboluteaand Marsileaquadrifolia. Plants that float on the surface and rooted on the bottom are included in thisgroup.

Rooted emergent with heterophile weeds represented by only one species such as Sagittaria Sp. Emergent aquatic macrophytes are defined as plants that are rooted in shallow water with vegetative parts emerging above the water surface. 
Free floating suspended submerged represented by six species such as Lemna minor, Azollacarolimana, Wolfia Sp., Salviniarotundifolia, Pistiastratiatesand Nymphoides. They rooted in mud along margin and send out long creeping and floating stem.

Rooted submerged hydrophytes represented by three species such as Potamogetoncrispus, Ipomoea aquatic and Hydrilla $\mathrm{Sp}$.

Emergent weeds are Commelina benghalensis, Cyperus rotundus, Grangea maderaspatana, Ipomoea camia, Merrimia emariginum, Scirpus articulates and Typha angustata.

Anchored Floating weeds represented by Nymphoides cristata

Submerged aquatic macrophytes are usually rooted in the bottom soil with the vegetative parts predominantly submerged.

Several workers have conducted macrophytes survey in lakes from different parts of India viz. Alwarlakes, Alwar, Rajasthan Vyas (1964), Udaipur lake, Udaipur, Rajasthan Paliwar (1984), Sagar lake, Sagar, Madhya Pradesh (Joshi et al., 1987), Sharma and Singhal (1988) recorded 11 species of macrophytes from a trophical lake. Sarrornagar lake, Hyderabad, Andhra Pradesh (Kodarkar, 1996), Meshram and Dhande (2000) also recorded the aquatic macrophytes in Wadali lake, Amraoti and stated that the macrophytes stimulate the growth of phytoplankton and help in the recycling of the organic matter. Ambasht (2005) recorded 25 species of macrophytes from Gujrat Tal, Jaunpurtownshio North India. Narayanaet al., (2006) study the aquatic macrophytes of Husain sagar, Karanataka. inKiranet al., (2006) recorded 15 species of macrophytes the fish culture ponds at Bhadra fish farm, Karnataka. Game and Salaskar (2007) recorded the macrophytes on Malchmali lakes, Thane, Maharashtra, Saltanat Malik and AtulNamdeo (2010) recorded the 21 species of macrophytes in a polluted pond of Shahjanpur, U.P., Sheikh, J.A. et al., (2011) reported 10 species of macrophytes in three eutrophic lakes of Jhansi, Bundelkhand region, Palit and Mukharjee (2012) recorded 25 species of macrophytes in wetlands of Bankara district, West Bengal and Harney et al., (2013) reported 19 species of macrophytes in three water bodies of Bhadrawati of Chandrapur District, Shashikant R. Sitre(2013) reported 17 macrophyte species in Ghotnimbala lake near Bhadrawati of Chandrapur district and Dhore M.M. et. al., (2014) recorded 15 species of macrophyte form some freshwater lakes of Yavatmal district.

\section{CONCLUSION}

The present paper describes the macrophytes biodiversity of Waigaon Tukum lake near Bhadrawati, District Chandrapur of Maharashtra State from January 2015 to December 2017 in which 26 species representing 17 families belonging to 8 groups such as 03 Submerged floating weeds, 03 Rooted floating leaves weeds, 01 Rooted emergent with heterophile weeds, 06 Free floating suspended submerged, 03 Rooted submerged hydrophytes, 07 Emergent weeds, 02 Submerged weeds and 01 Anchored floating weeds.

The aim of this study has therefore undertaken of document the aquatic macrophytes of Waigaon Tukum lake near Bhadrawati, District Chandrapur. The check list generated in the study is intended to support other research in wetlands and in particular, to assure the continuity of ongoing long term ecological programmed.

\section{REFERENCES}

AMBASHT, R.S. (2005) Macrophytes limnology in the Indian subcontinent. Ukaaz Publication, Hyderabad.pp.58-174. 
BEST, E.P.H. (1982) Effect of water pollution on freshwater submerged macrophytes. Water Pollution and Management review,27-56.

BHAUMIK, U, DAS, P, \& PARIA, T. (2004) Environment and Ecology, 22 (Spl-2):371.

BILLORE,D.K. \& VYAS, L.N. (1981) Int. J. Ecol. Sc. $7: 45$.

CROWDER, A.A., BRISTOW, J.M., KING, M.R. \& VANDER, K.S. (1977) Distribution, seasonality and biomass of aquatic macrophytes in lake Opnicon. Naturaliste., Can (104):441-456.

DHORE MUKUND MANOHAR AND LUCHARE PARESH SHYAM(2014) Survey of aquatic macrophyte diversity in Yavatmal district, Maharashtra, India. Int. J. of Life Sciences, Vol2(3) : 273-275.

DEVI, C.G. \& SHARMA, B.M. (2007) Studies on the diversity of the macrophytes in Awangsoipat Lake (Bishnupur), Manipur, India. In: (Eds. A.K. Kandya and Asha Gupta) Biodiversity conservation and Legal aspect. Aviskar Publishers, Distributors, Jaipur:62-71.

DEY, S.C. \& KAR, D. (1989) Environ. Eco. 7: 253.

GAME, A.S. \& SALASKAR, P.B. (2007) Environmental impact of macrophytes on Makhmali Lakes, Thane, Maharashtra. J. Aqua. Biol. 22(2):203-204.

GHAVZAN, N.J., GUNALE, V.R., MAHAJAN, D.M. \& SHRIKE, D.R. (2006) Effect of environmental factors on ecology and distribution of aquatic macrophytes. Asian journal of Plant Sciences, 5(5):871-880.

HARNEY N.V., A.A. DHAMANI \& R.J. ANDREW (2013) Biodiversity of macrophytes of three water bodies near Bhadrawati, districtChandrapur (M.S.), India. IJSR, Vol. 2(9): 437-439.

ISLAM, M. (1990) "Advance in plant sciences"12:35.

JAVID, A SHEIKH, G. JELLANI \& R.S. GAVALI (2011) Distribution of emergent macrophytes of three eutrophic lakes form Jhansi, Bundelkhand region. J. Res. and Deve., Vol. 11:41-48.

JOSHI, G., A.D. ADONI \& A.K. VAISHYA (1987) Ecology of Sagar Lake, Hyderabad IV (29): 151- 155.

KIRAN, B.R., PATEL, A.N., VIJAYA K. \& PUTTAIAH, E.T. (2006) Aquatic macrophytes in fish culture ponds at Bhadra fish farm, Karnataka. J. Aqua. Biol. 21(2):27-29.

KODARKAR, M.S. (1994) Conservation of Saroornagarlake. Hyderabad Bachao.3 (9) $: 21$.

KODARKAR, M.S. (1996) "Conservation of Lakes", IAAB Publication No. 3, IAAB,Hyderabad.

KUMAR, R. \& PANDIT, A. K. (2005) Community architecture of macrophytes in Hokarsar wetland, Kashmir, Ind. J. Environ. And Ecoplan. (10):565-573.

MESHRAM, C.B. \& DHANDE, R.R. (2000) Algae diversity with respect to pollution status of Wadali Lake, Amravati, Maharashtra, India. J. Aqua Biol. 15 (1 \&2):1-5

NARAYANA,J.,PURUSHOTHAMA,R.,KIRAN,B.R.,R AVINDRAKUMAR,K.P.\&PUTTAH,

E.T. (2005) Investigation of drinking water quality of Basavanahole Tank with reference to physical chemical characteristics. Fundamental of limnology, 201-206.

PALIT, D. \& MUKHARJEE, A. (2012) Studies on water quality and macrophytes composition in wetlands of Bankura district, West Bengal, India. Ind. J. Plant Sci. , Vol.1(2\&3):221-228.

RAUT, N. \& PEJAWAR, M. (2005) Survey of diversity of plankton attached to macrophytes from weed infested lake in Thane, Maharashtra. J. Aqua. Biol. 20(1):17. 
SALASKAR, P.B. (1998) "Some environmental aspects of Powai lake", Ph.D. Thesis, Mumbai University,Mumbai.

SALTANAT, ARA MALIK 7\& ATUL NAMDEO (2010) Enumeration of macrophytes in a polluted pond of Shahajanpur, U.P. (India) J. Phytology. Vol.2(9):14-17.

SEDDON, B. (1972) Aquatic macrophytes as limnological indicators. Freswat. Biol. (2):107-130.

SHARMA, ALKA \& SINGHAL, P.K. (1988) Impact of floating and emergent vegetation on the trophic

SHASHINAT R. SITRE(2013) Assessment of macrobiodiversity of a freshwater reservoir of Bhadrawati tahsil in Chandrapur district. OIIRJ . Vol. 3(3): 78-81.

\section{SHIMODA, MICHIKO (1984) Macrophytic} communities and their significance as indicator of water quality in two ponds in the Saijo basin, Hiroshima prefecture, Japan, Hikobia (9):1-14.

UNNI,K.S.(1971)Anecologicalstudyofthemacrophy ticvegetationofDoodhadharilake, Rajpur,

M.P. India I. Distribution and seasonal changes in aquatic plants. Hydrobiol. 37: 139-155.

ZUTSHI, D.P., SUBLA, B.A., KHAN, M.A. \& WANGANEO, A. (1980) Comparative limnology of nine lakes of Jammu and Kashmir, Himalaya. Hydrobiol. 72:101112.

Table 1 : Biodiversity of Macrophytes of Waigaon Tukum lake.

\begin{tabular}{|c|c|c|c|}
\hline $\begin{array}{l}\text { Sr. } \\
\text { No. }\end{array}$ & $\begin{array}{l}\text { Name of } \\
\text { macrophytes }\end{array}$ & Family & Life forms \\
\hline 1 & $\begin{array}{l}\text { Azollacarolima } \\
\text { na }\end{array}$ & Azollaceae & $\begin{array}{l}\text { Free floating } \\
\text { suspended } \\
\text { submerged }\end{array}$ \\
\hline 2 & $\begin{array}{l}\text { Ceratophy } \\
\text { llumechin } \\
\text { atum }\end{array}$ & $\begin{array}{l}\text { Ceratophy } \\
\text { llaceae }\end{array}$ & $\begin{array}{l}\text { Submerged } \\
\text { floating } \\
\text { weeds }\end{array}$ \\
\hline 3 & $\begin{array}{l}\text { Commelina } \\
\text { benghalensis }\end{array}$ & $\begin{array}{l}\text { Commelin } \\
\text { aceae }\end{array}$ & $\begin{array}{l}\text { Emergent } \\
\text { weeds }\end{array}$ \\
\hline 4 & $\begin{array}{l}\text { Cyperus } \\
\text { rotundus }\end{array}$ & $\begin{array}{l}\text { Cype } \\
\text { raceae }\end{array}$ & $\begin{array}{l}\text { Emergent } \\
\text { weeds }\end{array}$ \\
\hline 5 & $\begin{array}{l}\text { Grangea } \\
\text { maderaspatan } \\
a\end{array}$ & Asteraceae & $\begin{array}{l}\text { Emergent } \\
\text { weeds }\end{array}$ \\
\hline 6 & Hydrilla Sp. & $\begin{array}{l}\text { Hydrochar } \\
\text { itaceae }\end{array}$ & $\begin{array}{l}\text { Rooted } \\
\text { submerged } \\
\text { hydrophytes }\end{array}$ \\
\hline 7 & $\begin{array}{l}\text { Ipomoea } \\
\text { aquatica }\end{array}$ & $\begin{array}{l}\text { Convolvul } \\
\text { aceae }\end{array}$ & $\begin{array}{l}\text { Rooted } \\
\text { submerged } \\
\text { hydrophytes }\end{array}$ \\
\hline 8 & Ipomoea camia & $\begin{array}{l}\text { Convolvul } \\
\text { aceae }\end{array}$ & $\begin{array}{l}\text { Emergent } \\
\text { weeds }\end{array}$ \\
\hline 9 & Lemna minor & $\begin{array}{l}\text { Lemnacea } \\
\mathrm{e}\end{array}$ & $\begin{array}{l}\text { Free floating } \\
\text { suspended } \\
\text { submerged }\end{array}$ \\
\hline
\end{tabular}




\begin{tabular}{|c|c|c|c|}
\hline 10 & $\begin{array}{l}\text { Marsil } \\
\text { eaqua } \\
\text { drifoli } \\
\text { a }\end{array}$ & $\begin{array}{l}\text { Marsileace } \\
\text { ae }\end{array}$ & $\begin{array}{l}\text { Rooted } \\
\text { floating } \\
\text { leaves weeds }\end{array}$ \\
\hline 11 & $\begin{array}{l}\text { Merrimia } \\
\text { emariginum }\end{array}$ & $\begin{array}{l}\text { Convolvul } \\
\text { aceae }\end{array}$ & $\begin{array}{l}\text { Emergent } \\
\text { weeds }\end{array}$ \\
\hline 12 & $\begin{array}{l}\text { Myriophy } \\
\text { llumexalb } \\
\text { escens }\end{array}$ & $\begin{array}{l}\text { Haloragac } \\
\text { eae }\end{array}$ & $\begin{array}{l}\text { Submerged } \\
\text { floating } \\
\text { weeds }\end{array}$ \\
\hline 13 & Nelumbolutea & $\begin{array}{l}\text { Nymphaea } \\
\text { ceae }\end{array}$ & $\begin{array}{l}\text { Rooted } \\
\text { floating } \\
\text { leaves weeds }\end{array}$ \\
\hline 14 & $\begin{array}{l}\text { Nymp } \\
\text { haeat } \\
\text { ubero } \\
\text { sa }\end{array}$ & $\begin{array}{l}\text { Nymphaea } \\
\text { ceae }\end{array}$ & $\begin{array}{l}\text { Rooted } \\
\text { floating } \\
\text { leaves weeds }\end{array}$ \\
\hline 15 & $\begin{array}{l}\text { Nymphoides } \\
\text { cristata }\end{array}$ & $\begin{array}{l}\text { Menyanth } \\
\text { aceae }\end{array}$ & $\begin{array}{l}\text { Anchored } \\
\text { Floating } \\
\text { weeds }\end{array}$ \\
\hline 16 & $\begin{array}{l}\text { Nymphoides } \\
\text { indica }\end{array}$ & $\begin{array}{l}\text { Menyanth } \\
\text { aceae }\end{array}$ & $\begin{array}{l}\text { Free floating } \\
\text { suspended } \\
\text { submerged }\end{array}$ \\
\hline 17 & $\begin{array}{l}\text { Ottelia } \\
\text { alismoides }\end{array}$ & $\begin{array}{l}\text { Hydrochar } \\
\text { itaceae }\end{array}$ & $\begin{array}{l}\text { Submerged } \\
\text { weeds }\end{array}$ \\
\hline 18 & $\begin{array}{l}\text { Oxlis } \\
\text { corniculata }\end{array}$ & $\begin{array}{l}\text { Oxalidace } \\
\text { ae }\end{array}$ & $\begin{array}{l}\text { Submerged } \\
\text { weeds }\end{array}$ \\
\hline 19 & Pistiastratiates & Araceae & $\begin{array}{l}\text { Free floating } \\
\text { suspended } \\
\text { submerged }\end{array}$ \\
\hline 20 & $\begin{array}{l}\text { Potamog } \\
\text { etoncris } \\
\text { pus }\end{array}$ & Naidaceae & $\begin{array}{l}\text { Rooted } \\
\text { submerged } \\
\text { hydrophytes }\end{array}$ \\
\hline 21 & Sagittaria $S p$. & $\begin{array}{l}\text { Alismatac } \\
\text { eae }\end{array}$ & $\begin{array}{l}\text { Rooted } \\
\text { emergent } \\
\text { with } \\
\text { heterophile } \\
\text { weeds }\end{array}$ \\
\hline 22 & $\begin{array}{l}\text { Salvini } \\
\text { arotun } \\
\text { difolia }\end{array}$ & $\begin{array}{l}\text { Salviniace } \\
\text { ae }\end{array}$ & $\begin{array}{l}\text { Free floating } \\
\text { suspended } \\
\text { submerged }\end{array}$ \\
\hline 23 & $\begin{array}{l}\text { Scirpus } \\
\text { articulatus }\end{array}$ & $\begin{array}{l}\text { Cyperacea } \\
\mathrm{e}\end{array}$ & $\begin{array}{l}\text { Emergent } \\
\text { weeds }\end{array}$ \\
\hline 24 & $\begin{array}{l}\text { Typha } \\
\text { angustata }\end{array}$ & Typhaceae & $\begin{array}{l}\text { Emergent } \\
\text { weeds }\end{array}$ \\
\hline 25 & $\begin{array}{l}\text { Vallis } \\
\text { neria } \\
\text { ameri }\end{array}$ & $\begin{array}{l}\text { Hydrochar } \\
\text { itaceae }\end{array}$ & $\begin{array}{l}\text { Submerged } \\
\text { floating } \\
\text { weeds }\end{array}$ \\
\hline
\end{tabular}


I J R B A T, Issue (VIII), Vol. I, Jan 2020: 52-58

8

\begin{tabular}{|l|l|l|l|}
\hline & cana & & \\
\hline 26 & Wolfia $S p$. & $\begin{array}{l}\text { Lemnacea } \\
\text { e }\end{array}$ & $\begin{array}{l}\text { Free floating } \\
\text { suspended } \\
\text { submerged }\end{array}$ \\
\hline
\end{tabular}

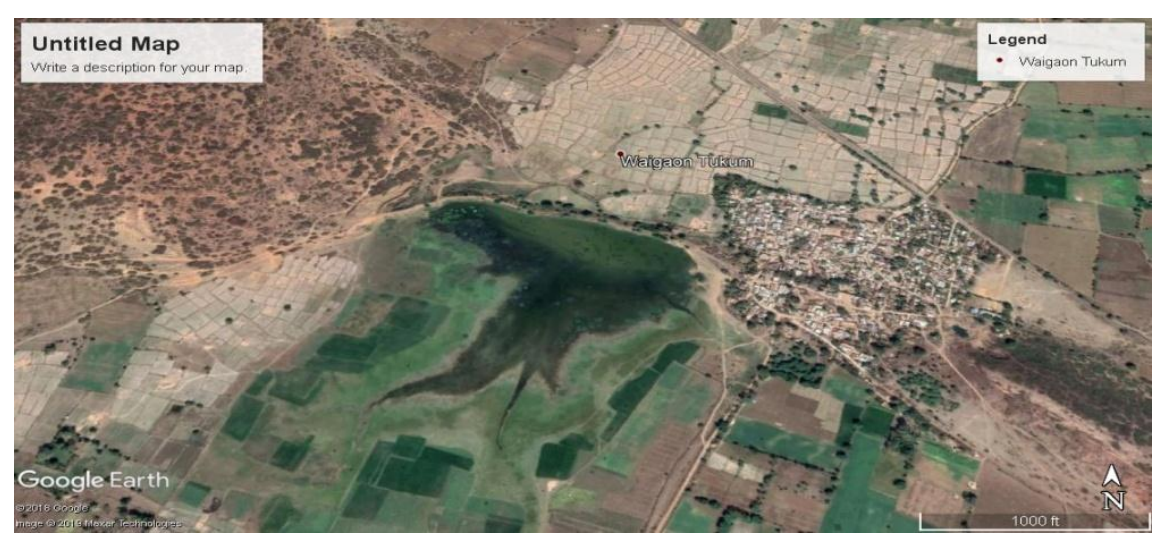

Fig. - Satellite image of Waigaon Tukum Lake 